\title{
VARIATIONS IN BIOLOGICAL ATTRIBUTES AND PHENOLICS OF ENZYMATICALLY HYDROLYSED MEDICINAL PLANT EXTRACTS
}

\author{
Rahman Qadir, Faroog Anwar*, Tahir Mehmood ${ }^{1}$, Sadaf Zahoor \\ AND NAUNAIN MEHMOOD ${ }^{2}$ \\ Department of Chemistry, University of Sargodha, Sargodha, Pakistan
}

Keywords: Kemzyme dry-plus, Natuzyme, Zympex-014, Biological activities, Phenolics

\begin{abstract}
Major objective of this study was to appraise the variations in biological activities and phenolics of enzymatically hydrolysed medicinal plants, namely Morus alba (L.), Momordica balsamina (L.), Capparis spinosa (L.), Pongamia pinnata (L.) and Peganum hermala (L.) indigenous to Pothoharic region of Pakistan. Enzyme cocktails such as kemzyme dry-plus, natuzyme and zympex-014 were employed for enzyme-assisted extraction. Best antimicrobial activity was exhibited by zympex-014 produced extracts against selected strains of bacteria and fungi with inhibition zone of 18.54 and $21.45 \mathrm{~mm}$, respectively. Similarly, zympex014 produced $C$. spinosa extract $(1.21 \%)$ exhibited least hemolytic activity. However, greater thrombolytic activity $(51.93 \%)$ was exhibited by kemzyme dry-plus produced $M$. balsamina extract. Moreover, major phenolics detected in selected medicinal plants using RP-HPLC were gallic acid $(272 \mu \mathrm{g} / \mathrm{g})$, quercitin $(269$ $\mu \mathrm{g} / \mathrm{g})$, benzoic acid $(184 \mu \mathrm{g} / \mathrm{g})$, vanillic acid $(100 \mu \mathrm{g} / \mathrm{g})$ and cinnamic acid $(68 \mu \mathrm{g} / \mathrm{g})$. Overall, the above results revealed that enzymatic pre-treatment facilitated in the liberation of bound phenolic moieties from selected medicinal plants and thus improved their biological attributes.
\end{abstract}

The use of wild plants for the treatment of different health disorders has been an ancient tradition in the folk system of Indo-Pak medicines (Muhammad et al. 2015). Even though allopathic medicines are extensively employed for medication, however, the treatment of different diseases and health problems using wild medicinal plants products is still a common practice, especially in rural communities of Pakistan. Pakistan is overwhelmingly an agricultural country and is blessed with diverse agro-ecological zones. In this regard, the Pothohar Plateau, forming the northern part of Punjab, is especially important due to its rich and valued biodiversity and flora of wild medicinal plants (Ahmad et al. 2016).

Natural antioxidants such as phenolics, found in various plant products may lessen the risks of various pathologies and improve general human health (Shahid et al. 2007, Zahoor et al. 2016). However, selection of an appropriate procedure is a key step for extraction of optimum amount of plant phenolics with potent biological activities (Sajid et al. 2012). To cope with the challenges of less efficient conventional extraction methods and in line with the green chemistry principles, a recent development in the area of plant bioactives extraction is the use of enzyme-assisted maceration (enzymatic pre-treatment) to facilitate and improve the recovery of phenolics from the compact and complex plant cell wall structures into the extraction solvent (Anwar et al. 2013).

The present study was mainly designed to evaluate the effect of different enzyme pretreated macerations on the yield, and biological attributes of phenolic components extracted from selected medicinal plants wildly growing in the Pothoharic region. The selected medicinal plants have not yet been explored for the phenolic bioactives profiling with the primary aim to link up and establish scientific basis for their traditional folk medicinal uses. Hence, this gap of scientific information prompts the need to screen the selected wild medicinal plants growing in and around

*Author for correspondence: <fqanwar@yahoo.com>. ${ }^{1}$ Institute of Biochemistry and Biotechnology, University of Veterinary and Animal Sciences - UVAS, Lahore, Pakistan ${ }^{2}$ Department of Zoology, University of Sargodha, Sargodha, Pakistan. 
Pothoharic region for their phenolic antioxidants/antimicrobial profiling and biological bioactivities.

Commercial enzyme mixtures (kemzyme dry-plus, natuzyme and zympex-014) were procured from local suppliers. All other chemicals (analytical grade) used in different experiments were purchased from Sigma-Aldrich Chemical Corporation, Germany.

Three different samples of the selected parts of medicinal plants such as leaves of M. alba, P. pinnata, $P$. hermala, and fruits of M. balsamina and C. spinosa were collected from Pothoharic region of Punjab, Pakistan. After ambient drying, the materials were ground into fine powder. For enzymatic pre-treatment/hydrolysis, the material was mixed with $15 \mathrm{ml}$ of phosphate buffer (6 - 9 $\mathrm{pH})$ in a flask and blended with selected enzyme complex $(0.5-6.5 \mathrm{~g})$ for $30-90 \mathrm{~min}$. After heating at $100^{\circ} \mathrm{C}$ for $10 \mathrm{~min}$ to deactivate the enzyme, the treated material was extracted in orbital shaker with $100 \mathrm{ml} 80 \%$ aqueous methanol and filtered $(0.22 \mu \mathrm{m})$ under pressure (Heidolph, Germany). After removal of excess solvent via distillation under reduced pressure using rotary evaporator, the crude concentrated extracts were obtained (Qadir et al. 2019).

Disc diffusion method was employed to evaluate antimicrobial activity of the extracts against Escherichia coli, Bacillus subtilis, Aspergillus flavus and Fusarium oxysporum (NCCLS, 1997). Rifamycin and fluconazole $(10 \mathrm{mg} / \mathrm{ml}, 10 \mu \mathrm{g} / \mathrm{disc})$ were used as positive references for bacteria and fungi, respectively.

By employing spectrophotometeric method, in vitro haemolytic activity was examined by taking measurement at $540 \mathrm{~nm}$ (Qadir et al. 2018). Phosphate buffer saline and Triton X-100 were used as negative and positive hemolytic controls, respectively.

Appraisal of antithrombotic activity was made by procedure described by Prasad et al. (2006) with slight modifications. Streptokinase (SK) was used as a positive control.

The most potent i.e., zympex-014 assisted extract was analysed by reversed phase high performance liquid chromatography (RP-HPLC) with little modifications (Abadio et al. 2012).

Antibacterial potential of the selected medicinal plant extracts was evaluated following the measurement of zone of inhibition (ZOI). The results indicated that B. subtilis was the most sensitive microorganism showing greater zone of inhibition, from $12-18 \mathrm{~mm}$ when exposed to the leaf extracts of P. pinnata among others (Table 1). However, E. coli showed better results upon exposure to the $M$. alba leaf extracts by showing zone of inhibition in the range of $12-16$ $\mathrm{mm}$. On the other side, the fruit extracts of M. balsamina exhibited lowest ZOI from the edges of paper disk $(4-8 \mathrm{~mm}$ and $5-8 \mathrm{~mm})$ against $E$. coli and B. subtilis, respectively. However, $C$. spinosa extract exhibited value in the range of $9-14 \mathrm{~mm}$ and $8-12 \mathrm{~mm}$ against $E$. coli and $B$. subtilis, respectively. Nevertheless, these activities were apparently lower than the drug (Rifamycin) used as positive control.

In case of antifungal activity, maximum ZOI was observed against $A$. flavus $(15-21 \mathrm{~mm})$ and $F$. oxysporum $(16-19 \mathrm{~mm})$ by $M$. alba extract. On the other side, lowest inhibition zones were expressed in case of A. flavus and $F$. oxysporum by $M$. balsamina extract ranging from $6-11 \mathrm{~mm}$ and $5-8 \mathrm{~mm}$, respectively (Table 2). Overall, the activity exhibited by zympex -014 extract was relatively higher in all cases except in $C$. spinosa, where kemzyme dry-plus extract showed superior activity.

Previous results reported by Bajpai et al. (2009), Wang et al. (2012) and Ines et al. (2014) confirm the present findings and support that enzyme-assisted extraction enhanced the bioactives, thereby resulting potent biological activities of plant extracts. 


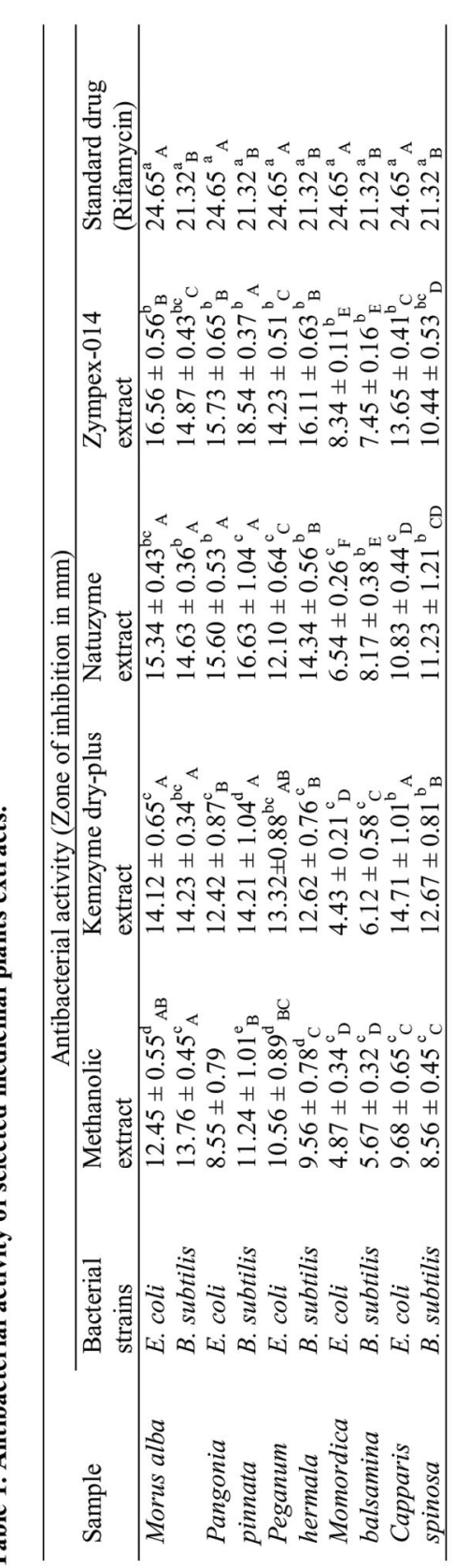

窟

苛

苞署

密

है

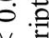

$\Leftrightarrow$

过

를

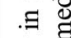

突

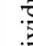

氜
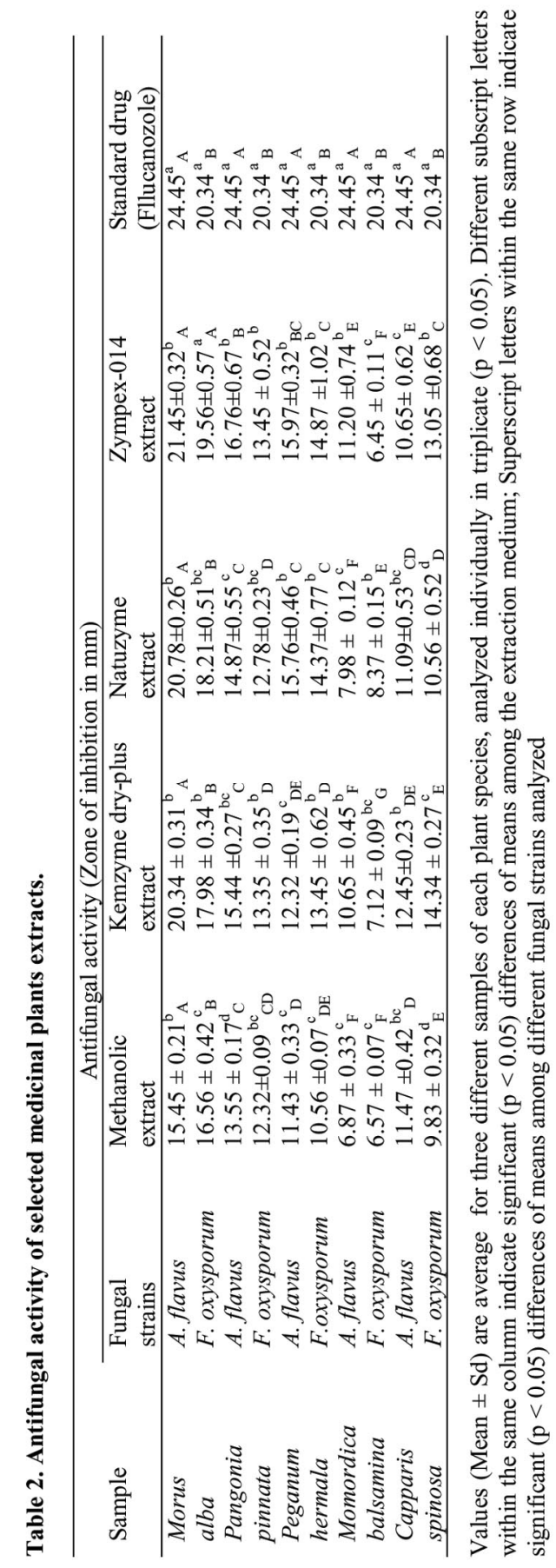


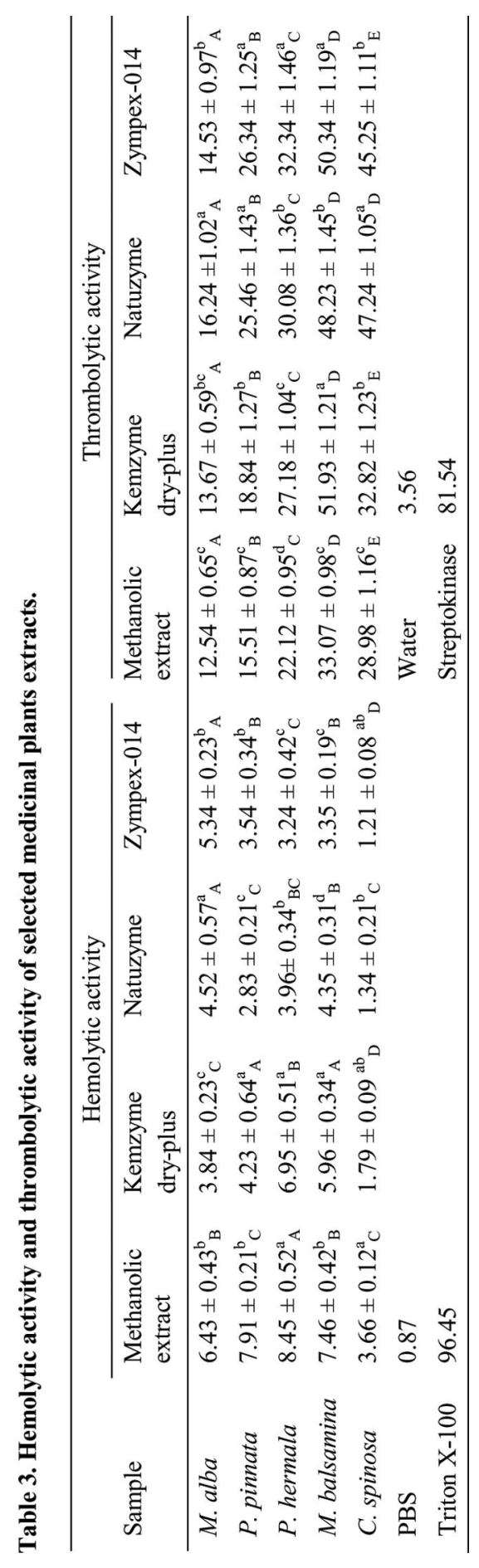


The hemolytic activity of selected medicinal plant extracts such as $M$. alba, P. pinnata, P. hermala, M. balsmaina and C. spinosa was noted to be in the range of $3.84-5.34,2.83-8.23$, $3.24-6.95,3.35-7.96$ and $1.34-2.34 \%$, respectively (Table 3). Overall, the highest hemolytic activity was observed for P. pinnata extract (8.23\%), recovered with kemzyme dry-plus, while the lowest activity was exhibited by the fruit extract of $C$. spinosa $(1.21 \%)$ which was extracted with zympex-014. Lower hemolytic activity $(<5 \%)$ directly relates to lower cytotoxic effects of natural products and this supports the potential uses of under study plant extracts in nutra-pharmaceutical industries (Qadir et al. 2018, Mehmood et al. 2019).

The results of the present study, showing that enzyme-assisted plant extracts have good activity relative to the control, can be supported by the previous findings of Sabah et al. (2012), Milad et al. (2014) and Suthin et al. (2014) who investigated enzyme-assisted extraction to be an effective process for optimal recovery of bioactive extracts.

Thrombolytic activity of the enzyme-assisted extracts obtained from the selected medicinal plants such as M. alba, P. pinnata, $P$. hermala, M. balsamina and C. spinosa was found to be in the range of $12-16,15-26,22-32,33-51$ and $28-47 \%$, respectively (Table 3). Streptokinase was used as a positive control $(81.54 \%)$. The highest thrombolytic activity was observed for kemzye dry-plus and zympex-014 based extracts of M. balsamina (51.93 and 50.34\%) while the lowest for methanolic extracts of $M$. alba and P. pinnata (12.54 and 15.51\%). In case of $C$. spinosa, the maximum thrombolytic activity was observed for natuzyme-based extract $(47.24 \%)$ while the minimum for control was methanolic extract (28.98\%).

Based on the results of thrombolytic activity, it can be conferred that zympex-014 based C. spinosa and M. balsamina extracts exhibited better activity compared to other tested extracts. As enzyme complexes have different extracting power to recover phenolic contents, therefore the difference in thrombolytic activity among different enzyme complexes might be related to their varying composition in addition to bioactives composition of plant.

Table 4. HPLC characterization of phenolics in selected medicinal plants (zympex-014-assisted plant extracts).

\begin{tabular}{|c|c|c|c|c|c|c|}
\hline \multirow{2}{*}{$\begin{array}{l}\text { Sl. } \\
\text { No. }\end{array}$} & \multirow[t]{2}{*}{ Phenolics } & \multicolumn{5}{|c|}{ Phenolics concentration $(\mu \mathrm{g} / \mathrm{g})$} \\
\hline & & M. alba & P. pinnata & P. hermala & M. balsamina & C. spinosa \\
\hline 1 & Quercetin & $102 \pm 3.51$ & $143 \pm 5.71$ & $132 \pm 3.51$ & $169 \pm 5.33$ & $175 \pm 2.71$ \\
\hline 2 & Gallic acid & $120 \pm 5.12$ & $164 \pm 6.52$ & $106 \pm 0.92$ & $107 \pm 1.84$ & $95 \pm 3.12$ \\
\hline 3 & Caffeic acid & ND & ND & $20 \pm 0.43$ & ND & ND \\
\hline 4 & Vanillic acid & $34 \pm 2.33$ & $41 \pm 1.55$ & ND & ND & ND \\
\hline 5 & Benzoic acid & $12 \pm 2.44$ & ND & $13 \pm 1.54$ & $14 \pm 2.32$ & $11 \pm 0.82$ \\
\hline 6 & $p$-coumaric acid & $17 \pm 0.55$ & ND & ND & ND & ND \\
\hline 7 & Chlorogenic acid & ND & $28 \pm 0.78$ & ND & ND & $30 \pm 1.63$ \\
\hline 8 & $m$-coumaric acid & $11 \pm 1.34$ & ND & $19 \pm 0.46$ & $13 \pm 0.51$ & $14 \pm 0.94$ \\
\hline 9 & Ferulic acid & ND & ND & ND & $36 \pm 0.89$ & ND \\
\hline 10 & Cinnamic acid & $35 \pm 2.36$ & $25 \pm 3.17$ & ND & ND & $28 \pm 1.9$ \\
\hline 11 & Sinapic acid & ND & ND & $19 \pm 1.17$ & $13 \pm 0.78$ & ND \\
\hline
\end{tabular}

$\mathrm{ND}=$ not detected

The most effective i.e., zympex-014-assisted plant extract was subjected to phenolics analysis by RP-HPLC that revealed the presence of a pool of phenolics (Table 4). Major phenolics detected were gallic acid, benzoic acid, quercetin, vanillic acid and cinnamic acid. The amount of gallic 
acid varied over a broad range, $46-271 \mu \mathrm{g} / \mathrm{g}$. Other important phenolic compounds such as caffeic acid and ferulic acid were present only in P. hermala and M. balsamina, respectively.

Previous HPLC results of $M$. alba and $P$. pinnata leaf extracts demonstrated the presence of $p$-hydroxybenzoic acid, vanillic acid, chlorogenic acid, $m$-coumaric acid (Ayaz et al. 2010, Sajid et al. 2012). Likewise, various phenolics were also identified and isolated from the methanolic extracts of C. spinosa (Yu et al. 2006, Tehseen et al. 2015). Moreover, the identified phenolic compounds are known to have antioxidant and other useful biological properties and this supports the medicinal and health promoting role of these phytochemicals.

\section{References}

Abadio F, Kammerer DR, Carle R, Tseng WH, Boser S and Graeve L 2012. Antioxidant activity and characterization of phenolic compounds from bacaba (Oenocarpus bacaba Mart.) fruit by HPLCDADMS. J. Agric. Food. Chem. 60: 7665-7673.

Ahmad N, Zuo Y, Lu X, Anwar F and Hameed S 2016. Characterization of free and conjugated phenolic compounds in fruits of selected wild plants. Food Chem.190: 80-89.

Anwar F, Zreen Z, Sultana B and Jamil A 2013. Enzyme-aided cold pressing of flaxseed (Linum usitatissimum L.): Enhancement in yield, quality and phenolics of oil. Grasas. Y. Aceites. 64: 463-471.

Ayaz AM, Najma M, Devanand LL, Bhanger MI and Amanat AP 2010. Phenolic acids profiling and antioxidant potential of mulberry (Morus laevigata W., Morus nigra, Morus alba L.) leaves and fruits grown in Pakistan. Pol. J. Food. Nutr. Sci. 60: 25-32.

Bajpai VK, Rahman A, Shukla S, Mehta S, Shukla S, Yassir SM, Rahman MM and Ferdousi Z 2009. Antibacterial activity of leaf extracts of Pongamia pinnata from India. Pharma. Bio. 47: 1162-1167.

Ines T, Walid E, Nizar T, Manel Z, Maria GC and Ali F 2014. Phenols, Flavonoids, and Antioxidant and Antibacterial Activity of Leaves and Stem Bark of Morus Species. Int J Food Properties. 17: 842-854.

Mehmood T, Afzal A, Anwar F, Iqbal M, Afzal M and Qadir R 2019. Variations in the composition, antibacterial and haemolytic activities of peel essential oils from unripe and ripened Citrus limon (L.) Osbeck fruit . J. Ess. Oil. Bear. Plants. 22(1): 159-168.

Milad M, Peyman M, Shahin A, Mohammad HA and Jalal S 2014. Pharmacological and therapeutic effects of Peganum harmala and its main alkaloids. Pharmaco. Reviews. 7: 199-205.

Muhammad G, Hussain MA, Anwar F, Ashraf M and Gilani AH 2015. Alhagi: A plant genus rich in bioactives for pharmaceuticals. Phyto. Res. 29: 1-13.

National Committee for Clinical Laboratory Standards (NCCLS). Approved Standard M2 A6, 1997, 5 th edn. NCCLS: Wayne, PA.

Prasad S, Kashyap, Deopujari RS, Purohit JY, Taori HJ and Daginawala HF 2006. Development of an in vitro model to study clot lysis activity of thrombolytic drugs. Thromb. J. 12: 10-14.

Qadir R., Anwar F, Batool F, Mushtaq M and Jabbar A 2019. Enzyme-assisted extraction of Momordica balsamina L. fruit phenolics: process optimized by response surface methodology. J. Food. Measur. Charact. 13: 697-706.

Qadir R, Anwar F, Mehmood T, Shahid M and Zahoor S 2018. Variations in chemical composition, antimicrobial and haemolytic activities of peel essential oils from three local Citrus cultivars. Pure. Appl. Biol. 7(1): 282-291.

Sabah B, Djamila A, Moufida A, Meriem D, Seddik K, Lekhmici A and Abderrahmane B 2012. Antihemolytic and antioxidant effects of medicinal plant Capparis spinosa L. J. Life. Sci. 6: 637-643.

Sajid ZI, Anwar F, Shabir G, Ghulam R, Alkharfy KM and Gilani AH 2012. Antioxidant, antimicrobial properties and phenolics of different solvent extracts from bark, leaves and seeds of Pongamia pinnata (L.) Pierre. Molecules. 17: 3917-3932.

Shahid I, Bhanger MI and Farooq A 2007. Antioxidant properties and components of bran extracts from selected wheat varieties commercially available in Pakistan. LWT: Food. Sci. Tech. 40: 361-367.

Suthin A, Waraporn S, Sukanya C and Voravuth S 2014. Antihemolytic activities of green tea, safflower, and mulberry extracts during Plasmodium berghei infection in Mice. J. Pathogens. 2014: 1-4. 
Tehseen G, Anwar F, Sultana B, Maria ACA and Nouman W 2015. Capparis species: A potential source of bioactives and high-value components: A review. Ind. Crops. Prod 67: 81-96.

Wang W, Yuangang Z, Yujie F and Thomas E 2012. In vitro antioxidant and antimicrobial activity of extracts from Morus alba L. leaves, stems and fruits. Amer. J. Chinese. Med. 40: 349-356.

Yu Y, Gao H, Tang Z, Song X and Wu L 2006. Several phenolic acids from the fruit of Capparis spinosa. Asian. J. Trad. Med. 1: 1-4.

Zahoor S, Anwar F, Mehmood T, Sultana B and Qadir R 2016. Variations in antioxidant attributes and individual phenolics of Citrus fruit peels in relation to different species and extraction solvents. Chil. J. Chem. Soc. 61: 2852-2857.

(Manuscript received on 28 July, 2018; revised on 22 April, 2019) 